\title{
Is Hunting-Loving Associated with Blood Oxygen Level?
}

\author{
Rizwan Ullah and Muhammad Imran Qadir* \\ Institute of Molecular Biology and Biotechnology, Multan, Pakistan \\ *Corresponding author: Muhammad Imran Qadir, Institute of Molecular Biology and Biotechnology, Multan, Pakistan
}

\begin{tabular}{ll}
\hline ARTICLE INFO & ABSTRACT \\
$\begin{array}{l}\text { Received: February 08, } 2019 \\
\text { Published: }\end{array}$ & $\begin{array}{c}\text { Objective of this study was to associate normal blood oxygen level and hunting like- } \\
\text { ness. The total number of subjects that took part in this project was 200.The subjects was } \\
\text { the learners of the Baha Uddin Zakariya University Multan, Pakistan. We measured the } \\
\text { oxygen level of blood of all these subjects in this project and deliberate their ideas regard }\end{array}$ \\
$\begin{array}{ll}\text { Citation: Rizwan U, Muhammad Im- } \\
\text { ran Q. Is Hunting-Loving Associated } \\
\text { with Blood Oxygen Level?. Biomed }\end{array}$ & $\begin{array}{l}\text { likeliness of the hunting. From the current study we conclude that there is no technical } \\
\text { relationship between peripheral oxygen saturation and hunting [1]. }\end{array}$
\end{tabular}

I Sci \& Tech Res 14(4)-2019. BJSTR. MS.ID.002598.

Keyword: Hunting likeliness; Blood oxygen level; Students, t Test; p-value

\section{Introduction}

The blood oxygen level test is the measurement of oxygen level and carbon dioxide level in the blood. This test also checks the acidic and basic level of the blood which is also known as PH of the blood. During breathing process our lungs take in oxygen and take out carbon dioxide. If the level of oxygen and carbon dioxide is not balance in the blood, then it means that our lungs are not working perfectly, and it also show that there is a problem in the lungs or kidneys. It is also known as oxygen saturation test. This test is used to check that our lungs working perfectly or not and acidic and basic levels of the blood. Hunting means to kill or trap an animal. Hunting of wildlife and undomesticated animals is done by human being for obtaining food and to remove predators which are dangerous to other animals and humans. Hunting is also a practice for obtaining fresh meal for humans [2,3].

\section{Material and Method}

About 200 subjects participated in the current study. These were the learners of the Bahauddin Zakariya University Multan, Pakistan. In these students 135 are female and 75 are male. We measure their blood oxygen level with oximeter device [4,5].

\section{Measurement of Blood Oxygen Level}

For measuring blood oxygen level, we use oximetry method. This method is developed by Takuo Aoyagi and Michio Kishi in 1972.
Most oximeter show the ratio of oxygenated and deoxygenated cell in term of percent known as $\mathrm{SpO}_{2}$. Normal $\mathrm{SpO}_{2}$ is generally above $95 \%$. To use oximeter first insert batteries. Insert the finger to pulse oximeter and wait power on the device. After five second reading will starts. The yellow digits on the left are $\mathrm{SpO}_{2}$. This indicates the oxygen saturation percentage of your blood. Inaccurate reading can be caused by poor circulation; too much movement etc. nail polish has no effect on pulse oximeter reading [6,7].

$$
\mathrm{SpO}_{2}=\mathrm{HbO}_{2} / \mathrm{Hb}
$$

Where $\mathrm{Hbs}$ is haemoglobin with oxygen and $\mathrm{Hb}$ is haemoglobin without oxygen.

\section{Project Design}

A questionnaire was ready about hunting likeliness. About 200 students were participated in this project. These were learners of the Bahauddin Zakariya University Multan, Pakistan. We measured the oxygen saturation of these students with the help of accurate pulse oximeter and examine their opinion about hunting likeliness [8].

\section{Statistical Analysis}

Statistical analysis was performed by MS Excel Table 1. 
Table 1: Relation of peripheral oxygen saturation (Mean \pm SD) with Hunting.

\begin{tabular}{|c|c|c|c|}
\hline Gender & Hunting likeness & Hunting dislikeness & p-value \\
\hline Male & $96.41 \pm 4.66$ & $96.1 \pm 4.49$ & 0.79 \\
\hline Female & $96.00 \pm 5.93$ & $95.37 \pm 7.62$ & 0.25 \\
\hline Both & $96.20 \pm 4.91$ & $95.94 \pm 6.47$ & 0.37 \\
\hline
\end{tabular}

$p>0.05$

\section{Result \& Discussion}

About 200 subjects take part in this project. We measure their blood oxygen level with accurate device pulse oximeter and associate to the hunting likeliness. It was concluded that those students having normal $\mathrm{SpO}_{2}$ rate having no relation with hunting likeliness. $p>0.05$ is considered as significant $[9,10]$.

\section{Conclusion}

It was concluded from the present-day study that there is no relation between blood oxygen level and hunting loving.

\section{References}

1. Qadir MI, Malik SA (2010) Comparison of alterations in red blood cell count and alterations in hemoglobin concentration in patients suffering from rectal carcinoma undergoing 5 -fluorouracil and folic acid therapy Pharmacologyonline Nl 3: 240-243.

2. Qadir MI, Noor A (2018) Rare Anemias. \& Uncommon Diseases, Cambridge Scholars Publishing. Newcastle, England. ISBN: 978-1-52751807-0.

\section{ISSN: 2574-1241}

DOI: 10.26717.BJSTR.2019.14.002598

Muhammad Imran Qadir. Biomed J Sci \& Tech Res

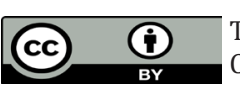

This work is licensed under Creative Commons Attribution 4.0 License

Submission Link: https://biomedres.us/submit-manuscript.php
3. Qadir MI, Javid A (2018) Awareness about Crohn's Disease in biotechnology students. Glo Adv Res J Med Medical Sci 7(3): 062-064.

4. Qadir MI, Saleem A (2018) Awareness about ischemic heart disease in university biotechnology students. Glo Adv Res J Med Medical Sci 7(3): 059-061.

5. Qadir MI, Ishfaq S (2018) Awareness about hypertension in biology students. Int J Mod Pharma Res 7(2): 08-10.

6. Qadir MI, Mehwish (2018) Awareness about psoriasis disease. Int J Mod Pharma Res 7(2): 17-18.

7. Qadir MI, Shahzad R (2018) Awareness about obesity in postgraduate students of biotechnology. Int J Mod Pharma Res 7(2): 14-16.

8. Qadir MI, Rizvi M (2018) Awareness about thalassemia in post graduate students. MOJ Lymphology \& Phlebology 2(1): 14-16.

9. Qadir MI, Ghalia BA (2018) Awareness survey about colorectal cancer in students of M. Phil Biotechnology at Bahauddin Zakariya University, Multan, Pakistan. Nov Appro in Can Study 1(3).

10. Qadir MI, Saba G (2018) Awareness about intestinal cancer in university student. Nov Appro in Can Study 1(3).

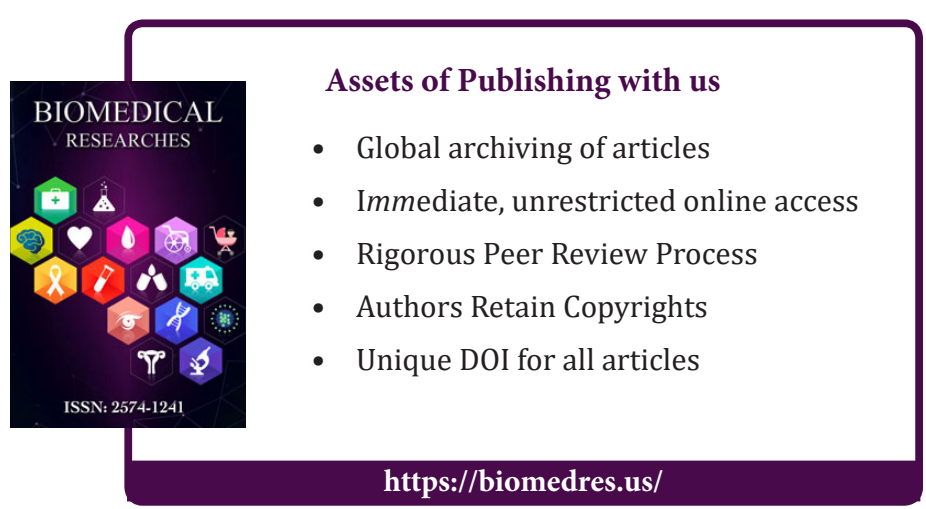

